\title{
Paclitaxel inhibits growth, migration and collagen production of human Tenon's fibroblasts-potential use in drug-eluting glaucoma drainage devices
}

\author{
Lars Choritz • Jochen Grub • Maria Wegner • \\ Norbert Pfeiffer • Hagen Thieme
}

Received: 14 July 2009 /Accepted: 7 October 2009/Published online: 7 November 2009

(C) The Author(s) 2009. This article is published with open access at Springerlink.com

\begin{abstract}
Objective/Aim One of the factors limiting the long-term success of glaucoma drainage devices and traditional filtering surgery is the tendency of bleb encapsulation. Glaucoma shunts present an opportunity of introducing drug-eluting mechanisms for a lasting exposure of the bleb to anti-proliferative substances. The aim of this in vitro study was to investigate the effects of short- and long-term exposure of primary cultures of human Tenon's fibroblasts to different concentrations of paclitaxel on cell proliferation, migration, collagen production and cytotoxicity, in order to evaluate the suitability of the drug for the use in such a device.

Materials/Methods Seven individual primary cultures of human Tenon's fibroblasts were observed over the course of 1 week after administering paclitaxel concentrations varying from $10^{-9} \mathrm{~mol} / 1$ to $10^{-6} \mathrm{~mol} / \mathrm{l}$ for either 1 hour or continuously. Relative cell count and migration across a cell-free area introduced by scratching through a confluent cell layer were determined every 24 hours, using photomicrographs of the cells for each concentration and exposure time. Soluble collagen concentration in the cell
\end{abstract}

The authors have no commercial relationship or interests to claim.

L. Choritz $\cdot$ J. Grub $\cdot$ N. Pfeiffer $\cdot$ H. Thieme

Department of Ophthalmology, University Medical Center of the

Johannes Gutenberg University,

Mainz, Germany

\section{Wegner}

Max Planck Institute for Polymer Research,

Mainz, Germany

\section{H. Thieme $(\bowtie)$}

Universitätsaugenklinik Mainz,

Langenbeckstr. 1,

55131 Mainz, Germany

e-mail: thieme@augen.klinik.uni-mainz.de culture medium was determined using a Sircol collagen assay 72 hours after paclitaxel exposure. Cytotoxicity of the compound was assessed by flow cytometry using dual staining with annexin V-FITC and propidium iodide.

Results Paclitaxel dose-dependently inhibited both proliferation and migration of the cells. Cell count was reduced at all concentrations and both exposure times $(p=0.001)$; similarly, all but two concentrations of paclitaxel caused a significant reduction of cell migration $(p<0.001)$. This may be explained in part by the dose- and time-dependent induction of apoptosis in up to $23.7 \%$ of the cells (maximal effect at $10^{-6} \mathrm{~mol} / \mathrm{l}, 7$ days after exposure). Collagen production was significantly reduced at all concentrations and at both exposure times. However, no statistically significant difference was observed between any of the concentrations, indicating that this inhibition may be an indirect effect.

Conclusion Paclitaxel may be a useful addition to the repertoire of anti-proliferative substances currently in use in glaucoma filtering surgery and shunt implantation. Further studies of the compound and its effects on Tenon's fibroblasts as well as other ocular tissues are warranted.

Keywords Glaucoma · Filtering surgery · Glaucoma drainage device $\cdot$ Paclitaxel $\cdot$ Proliferation - Migration . Cell culture $\cdot$ Tenon's fibroblasts

\section{Introduction}

Scar formation following filtering glaucoma surgery is one of the most difficult problems limiting the lasting success of this type of intervention. Despite the use of antiproliferative substances such as mitomycin C (MMC) or the anti-metabolite 5-fluorouracil (5-FU), the intermediate 
and long-term success rates of trabeculectomies in numerous studies, using a variety of different doses and exposure times, do not exceed $55-73 \%[1,2]$ for complete and $73-$ $91 \%[1,3]$ for qualified success. Although the mechanisms involved in scar tissue formation after filtering surgery are not fully understood, it is evident that excessive proliferation of fibroblasts from Tenon's capsule and conjunctiva, transdifferentiation of these fibroblasts into myofibroblasts, as well as uncontrolled production of extracellular matrix (ECM) play a major role in the process. Factors contributing to the problem include inflammation, increased levels of transforming growth factor beta (TGF-beta $_{2}$ ) in the drained aqueous humor $[4,5]$ and an increased expression of TGFbeta type II receptor in the fibroblasts of the bleb [6].

An even worse situation is seen in cases where glaucoma drainage devices (GDD) such as the classic Molteno or Baerveldt devices or the valved Ahmed device are used. Rapid encapsulation within months after initial implantation occurs in up to $30 \%$ of pediatric patients (own unpublished data), necessitating follow-up surgery to remove the fibrous capsules. This may be due to continuous sub-clinical inflammation caused by the base plates of the devices which results in increased scar tissue formation. The inflammatory response has been linked to the biomaterial of the devices [7, 8], as well as other physical properties such as size and shape of the endplates $[9,10]$. Furthermore, studies have shown that MMC does not improve the long-term outcome of GDD-implantation [11-14]. Thus, new and more effective ways to inhibit excessive scar formation are needed.

Paclitaxel is a compound from taxus brevifolia that is used successfully in the treatment of malignant solid tumors such as ovarian and breast cancer as well as non small cell lung cancer (NSCLC) [15]. Paclitaxel binds to and stabilizes microtubules of the mitotic spindle, and thereby inhibits cell division. It induces apoptosis in these tumor cells by mechanisms involving microtubule-associated caspases. Paclitaxel has also been shown to inhibit the growth of fibroblasts at low concentrations in various fibrosis models, in part by interfering with TGF-beta signaling $[16,17]$.

One interesting application of the substance is its extended release from coated coronary stents, which has led to decreased rates of re-stenosis of coronary arteries after intervention [18]. We wanted to explore the possibility of using paclitaxel as an anti-proliferative compound for a drug-eluting glaucoma drainage device. The aim of this study therefore was to investigate whether extended exposure of human Tenon's fibroblasts (HTF) to various low concentrations of paclitaxel can inhibit proliferation, migration and collagen production of these cells in vitro, to assess potential cytotoxicity and compare all of the effects to those seen after an only brief exposure to the compound.

\section{Materials and methods}

Human Tenon's fibroblast cell culture

Small samples of approximately $1-2 \mathrm{~mm}^{3}$ of Tenon's capsule were procured sterilely from donor eyes of the local eye bank no more than 5 hours post mortem, if the donors had consented to the scientific use of excess material. The tissue samples were transferred into a standard $60 \mathrm{~mm}$ cell culture dish, covered with a $20 \mathrm{~mm}$ glass cover slip, supplied with culture medium (Dulbecco's modified Eagle medium (DMEM), supplemented with $10 \%$ fetal calf serum (FCS) and $1 \%$ penicillin/streptomycin) and then placed in a $37^{\circ} \mathrm{C}$, $5 \% \mathrm{CO}_{2}$-containing incubator. After 1-2 weeks, when cells had grown out about $1.5 \mathrm{~cm}$ from the tissue sample, cells were passaged into $25 \mathrm{~cm}^{2}$ culture flasks using the Trypsin/ EDTA method. This was considered passage one. All further passages followed the same method, dividing the cells into three equal fractions each time. Seven individual cell lines were established in this fashion, dubbed HTF-1 to HTF-7. Identity of the cells was confirmed immunocytologically by staining for CD90, using the commercially available monoclonal antibody AS02 (Dianova, Germany). For each experimental series, cells from all cell lines, each from the same passage, were used. Overall, only passages four to six were utilized. Tissue procurement and all experiments adhered to the Declaration of Helsinki.

\section{Proliferation}

HTF cells were seeded into 12 -well plates at a cell density of 2,500 cells per well. Over the course of 1 week, four photographs of the cells were taken at predefined spots of each well every 24 hours, using a standard CCD camera attached to an inverted stage microscope (Leica DM IL, Wetzlar, Germany). The cells were counted using ImageJ (v.1.41); the mean number of cells per photograph on each day was used as one data point. Cell count of HTF cells incubated with medium plus vehicle $(0.1 \%$ ethanol) was compared to that of cells treated with different concentrations of Paclitaxel (Sigma-Aldrich, Steinheim, Germany; range $10^{-9} \mathrm{~mol} / 1$ to $10^{-6} \mathrm{~mol} / \mathrm{l}$ ), which were exposed to the compound either for 1 hour or continuously during the entire time of observation.

\section{Scratch-migration assays}

In order to determine the migratory activity of HTF cells treated with paclitaxel, the cells were seeded into 24-well plates and allowed to grow to confluence. Using a standard pipette tip, a scratch was then introduced through the centre of each well. The detached cells were washed off with PBS, leaving a clean, cell-free area of 550-600 $\mu \mathrm{m}$ width in each 
well. Cell culture medium containing varying concentrations of Paclitaxel $\left(10^{-9} \mathrm{~mol} / 1\right.$ to $\left.10^{-6} \mathrm{~mol} / \mathrm{l}\right)$ or vehicle alone was added to the wells. The width of the scratch over the course of 1 week was determined using photographs taken every 24 hours, employing the ImageJ software.

\section{Collagen assays}

The colorimetric Sircol soluble collagen assay (Biocolor Ltd., UK) uses a dye that specifically binds to the native triple helix structure of collagen. This dye is added in excess amounts to a collagen-containing solution (e.g. tissue homogenate or supernatant cell culture medium) and thoroughly mixed. Through centrifugation of the dye/ sample mix (10,000 $\mathrm{g}$ for 10 minutes), a pellet of collagen with bound dye forms; the supernatant with unbound dye is discarded. The pellet (and with it the dye) is then dissolved in an acidic solution provided with the kit; the photometric absorbance of the dyed solution is directly proportional to the amount of collagen in the sample.

For our study, HTF cells from all seven cell lines were seeded into three $25 \mathrm{~cm}^{2}$ culture flasks each and allowed to grow to $90 \%$ confluence. The culture medium used differed from the medium in all other experiments, in that it was supplemented with only $2 \%$ FCS, so as not to interfere with the sircol dye. Upon reaching near-confluence, cell culture medium was removed, cells were washed with PBS, and $1 \mathrm{ml}$ of culture medium was added back to each of three flasks from each cell line. Two of the flasks received $1 \mathrm{ml}$ of medium containing paclitaxel $\left(10^{-9} \mathrm{~mol} / \mathrm{l}\right.$ to $\left.10^{-6} \mathrm{~mol} / \mathrm{l}\right)$, the control received medium-containing vehicle only $(0.1 \%$ ethanol). After 1 hour of incubation, the medium from one of the paclitaxel-containing flasks was again removed, cells were washed again with PBS, and $1 \mathrm{ml}$ of medium plus vehicle were added. After 72 hours of further incubation, medium was collected from all flasks, cell debris removed from the samples by centrifugation (500 $\mathrm{g}$ for $5 \mathrm{~min}$ ), and collagen concentration was determined as described above. Since we used only the culture medium for our measurements, only the concentration of the soluble collagenwhich had been released from the cells and did not have time to crosslink into larger structures - was determined, thus giving an estimate of the current rate of collagen production of the cells. In order to adjust for antiproliferative or cytotoxic effects of paclitaxel, the treated cells were detached and counted, and collagen concentration was expressed as relative to control.

\section{Flow cytometry}

The rate of apoptosis and necrosis of the cells were determined by flow cytometry (FACSCalibur, BD Heidelberg, Germany) using dual staining with annexin V-FITC and propidium iodide
(Annexin-FLUOS staining kit, Roche Diagnostics, Germany) as described by Crowston et al. [19]. Measurements were performed in three of the seven cell lines (HTF-4, 6, and 7, randomly chosen) at three different time points $(24,96$, and 168 hours after initial exposure to Paclitaxel). At these time points, culture medium and PBS rinsing solution (potentially containing dead cells) were collected and joined with the cell suspension obtained through trypsination of each sample. The cells were pelleted through centrifugation (1000 rpm for $5 \mathrm{~min}$ at room temperature), and then resuspended in $100 \mu \mathrm{l}$ PBS. This cell suspension was added to $100 \mu \mathrm{l}$ of buffer containing $2 \mu \mathrm{l}$ each of FITC-labelled annexin $\mathrm{V}$ and propidium iodide, and allowed to incubate for $15 \mathrm{~min}$ in the dark. During this time, annexin V binds to phosphatidylserine that is exposed in the cell membranes of both necrotic and apoptotic cells but inaccessible in viable cells. Propidium iodide cannot permeate the otherwise intact cell membrane of apoptotic cells, but enters necrotic cells and intercalates in the nuclear DNA of these cells. Thus, by plotting fluorescence intensity of annexin V-FITC (detection wavelength: $530 \mathrm{~nm}, \mathrm{FL}-1)$ vs propidium iodide $(650 \mathrm{~nm})$, apoptotic cells can be distinguished from viable and necrotic cells. Analysis of the obtained data was performed using the BD Software CellQuest Pro (v4.0.1).

\section{Statistical analysis}

Unless stated otherwise, all results are expressed as mean \pm standard error of the mean. Following the methods described by Ludbrook [20], we employed repeated measures ANOVA for the growth and scratch-migration assays as well as the flow-cytometric measurements, in order to determine differences in the effects of the various concentrations of paclitaxel. For the collagen assays, two way ANOVA with post hoc tests for differences between the various concentrations and exposure times were used. Global significance was assumed at $p<0.05$; local levels of significance were adjusted using the Greenhouse-Geisser method to correct for sample asphericity - which necessarily occurs in this type of experimental set-up (proliferation and migration assays) - or the Bonferroni correction for multiple testing (collagen assay). All analyses were performed using SPSS 17 Advanced Module (SPSS Inc.).

\section{Results}

Proliferation

There was a dose-dependent decrease in cell growth for HTF cells exposed to paclitaxel for 1 hour compared to control, which was significant at all tested doses. As shown 
in Fig. 1, relative cell count on day 7 of the observation was $355.9 \pm 30.1 \%$ in the control vs $212.4 \pm 24.5 \%(p<0.004)$, $187.3 \pm 17.2 \% \quad(p<0.001), 101.4 \pm 5.4 \% \quad(p<0.003)$, and $72.7 \pm 4.5 \%(p<0.001)$ in the cells treated with paclitaxel $10^{-9} \mathrm{~mol} / 1,10^{-8} \mathrm{~mol} / 1,10^{-7} \mathrm{~mol} / 1$, and $10^{-6} \mathrm{~mol} / 1$ respectively. Continuous exposure to paclitaxel did not only abolish growth of the cells but also led to a significant dosedependent cell loss. Relative cell count increased in untreated cells to $774.4 \pm 113.4 \%$, but decreased to $43.2 \pm$ $14.7 \% \quad(p<0.014), 30.6 \pm 6.6 \% \quad(p<0.016), 20.6 \pm 5.3 \%$ $(p<0.013)$ and $13.8 \pm 4.9 \%(p<0.001)$ in the cells treated with $10^{-9} \mathrm{~mol} / 1,10^{-8} \mathrm{~mol} / 1,10^{-7} \mathrm{~mol} / 1$, and $10^{-6} \mathrm{~mol} / 1$ of paclitaxel (see Fig. 2). Although there was a trend toward a decreasing cell count with increasing concentrations of paclitaxel, no significant difference between any of the treatment groups with continuous exposure could be detected.

\section{Scratch-migration assays}

Figures 3 and 4 depict the development of the width of the scratch prepared in confluent monolayers of HTF cells as described above over the course of 1 week. In cells exposed to paclitaxel for only 1 hour, there was a trend toward slower closure of the cell-free gap. This difference was statistically significant in all but one concentration $\left(10^{-8} \mathrm{~mol} / \mathrm{l}\right)$. The hypothesis of equality of all groups was rejected on the basis of a global $p$-value of $<0.001$, with $p<0.003\left(10^{-9} \mathrm{~mol} / \mathrm{l}\right), \quad p=0.076\left(10^{-8} \mathrm{~mol} / \mathrm{l}\right), \quad p<0.004$ $\left(10^{-7} \mathrm{~mol} / \mathrm{l}\right)$, and $p<0.002\left(10^{-6} \mathrm{~mol} / \mathrm{l}\right)$ for post-hoc comparisons between control and each of the concentrations. On day 7, there was a mean width of $38.8 \pm 14.1 \mu \mathrm{m}$ in the $10^{-6} \mathrm{~mol} / \mathrm{l}$ group, whereas in the control and the cells treated with $10^{-9} \mathrm{~mol} / 1,10^{-8} \mathrm{~mol} / 1$, and $10^{-7} \mathrm{~mol} / 1$ of paclitaxel the gap had closed on days 2, 3, 4 and 6 respectively. A more prominent effect was observed after continuous treatment of the cells with paclitaxel. While in the wells treated with vehicle alone the scratch had closed after 2 days, there still remained a cell-free area with a mean width of $34.1 \pm 29.9 \mu \mathrm{m}$ for $10^{-9} \mathrm{~mol} / \mathrm{l}(p=0.142$, not significant), $20.4 \pm 16.6 \mu \mathrm{m}$ for $10^{-8} \mathrm{~mol} / 1(p=0.039)$, $77.2 \pm 28.4 \mu \mathrm{m}$ for $10^{-7} \mathrm{~mol} / 1(p=0.006)$ and $391.7 \pm$ $70.9 \mu \mathrm{m}$ for $10^{-6} \mathrm{~mol} / \mathrm{l}(p<0.001)$ of paclitaxel on day 7 of the observation. A sample photograph for untreated (Fig. 5a and b) and treated (Fig. 5c and d) cells immediately after and $48 \mathrm{~h}$ after the scratch is shown in Fig. 5. The morphological changes in the cells observed at higher concentrations of paclitaxel can also be assessed in this microphotograph (Fig. 5d).

\section{Collagen assays}

Medium samples taken 72 hours after treatment with vehicle (control) or paclitaxel for either 1 hour or 72 hours revealed a slight, but statistically significant decrease in collagen production of the treated cells. After brief
Fig. 1 Relative HTF cell count over a course of 7 days after exposure of the cells to different concentrations of paclitaxel for 1 hour




Fig. 2 Relative HTF cell count over a course of 6 days with continuous exposure of the cells to different concentrations of paclitaxel

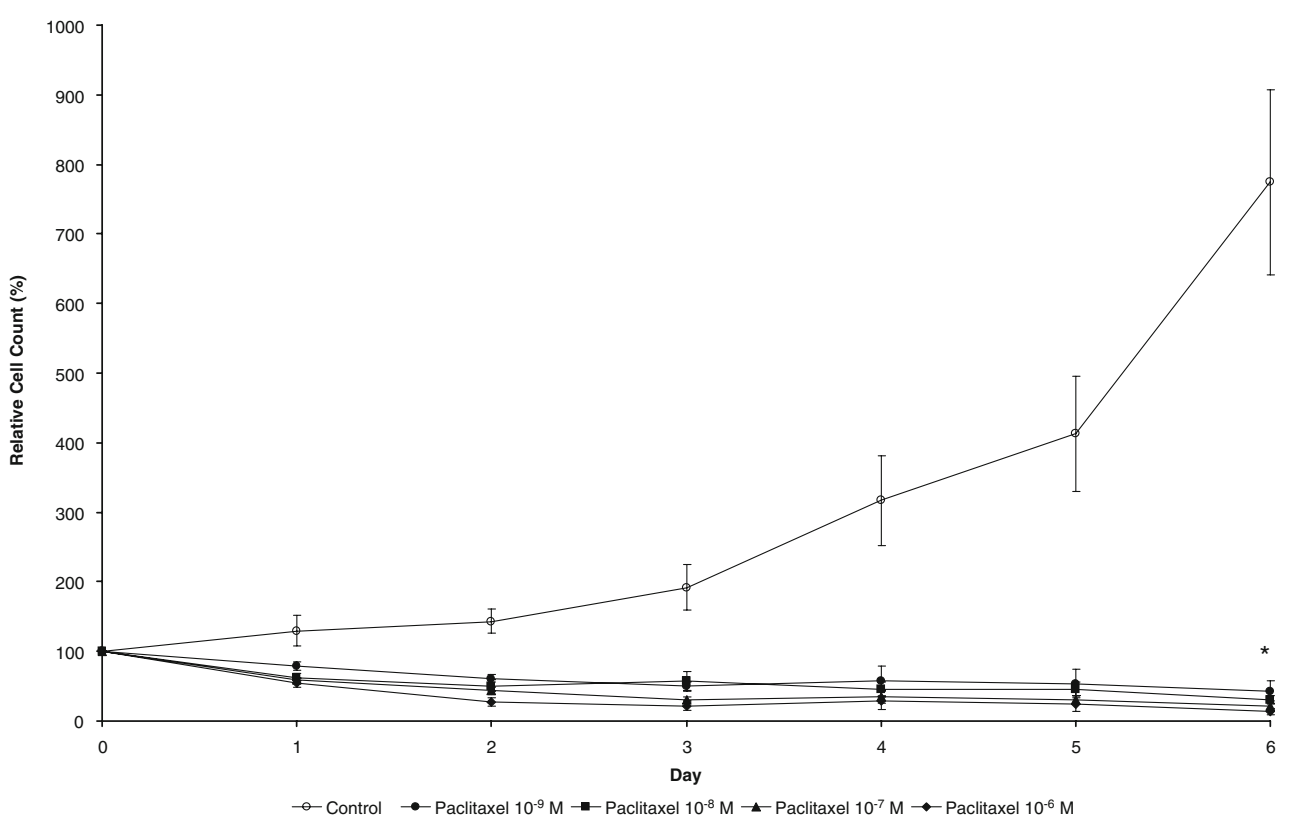

exposure to paclitaxel, the relative concentration compared to control of soluble collagen was reduced to $71.7 \pm 8.0 \%$ $(p=0.006), 79.0 \pm 4.0 \% \quad(p<0.001), 86.7 \pm 4.0 \% \quad(p=0.005)$ and $82.9 \pm 5.4 \%(p=0.011)$ for treatment concentrations of $10^{-6} \mathrm{~mol} / 1,10^{-7} \mathrm{~mol} / 1,10^{-8} \mathrm{~mol} / 1$ and $10^{-9} \mathrm{~mol} / 1$. In the cells treated continuously for 72 hours, collagen concentration dropped to $70.7 \pm 7.4 \% \quad(p=0.004), 73.5 \pm 12.1 \%$ $(p=0.041), 69.4 \pm 8.5 \% \quad(p=0.003)$ and $77.1 \pm 6.2 \% \quad(p=$ $0.005)$ respectively. Interestingly, there was no statistical difference between any of the various concentrations of paclitaxel nor between exposure times (Fig. 6).

Flow cytometry

The mean rate of apoptosis increased in a dose- and timedependent fashion to $22.5 \pm 8.1 \%$ on day 7 for cells exposed to $10^{-6} \mathrm{~mol} / \mathrm{l}$ of paclitaxel for 1 hour. Rate of apoptosis was $14.1 \pm 4.1 \%, 3.8 \pm 0.9 \%$, and $3.5 \pm 1.1 \%$ for $10^{-7} \mathrm{~mol} / \mathrm{l}$,
Fig. 3 A cell-free area was introduced by scratching a pipette tip through a confluent monolayer of HTF cells. The absolute width of this scratch after treatment of the cells with different concentrations of paclitaxel for 1 hour was observed over a period of 7 days

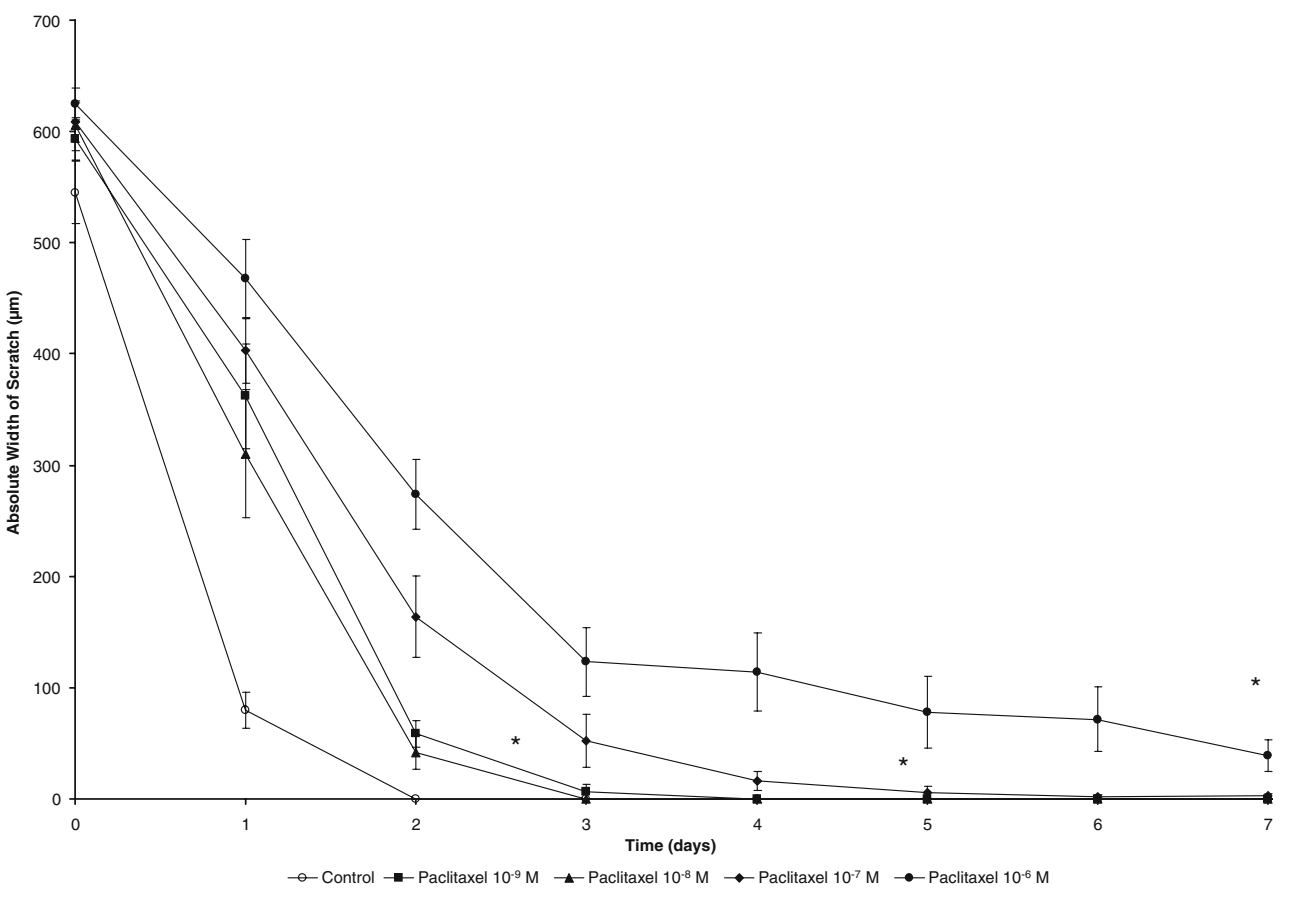


Fig. 4 Absolute width of the cell-free area during 1 week of continuous treatment of the cells with different concentrations of Paclitaxel


Fig. 5 Sample photographs of cells immediately after introducing an approximately $600 \mu \mathrm{m}$-wide scratch in a confluent monolayer of cells (a, c), and 48 hours later, after continuous treatment with $10^{-6} \mathrm{~mol} / \mathrm{l}$ paclitaxel (d) or vehicle (b). In the "untreated" control the

gap has closed with only a few remaining cell-free areas, whereas in the treated dish, the gap is virtually unchanged. Noteworthy are the morphologic changes in the treated cells, which are seen at concentrations exceeding $10^{-7} \mathrm{~mol} / 1$ of paclitaxel (d) 
Fig. 6 Relative concentration of soluble collagen in the culture medium of untreated control and cells exposed to either 1 hour or 72 hours of paclitaxel at different concentrations. The treated cells produce significantly less collagen than the control cells; however, no difference was found between different concentrations of paclitaxel or different treatment times

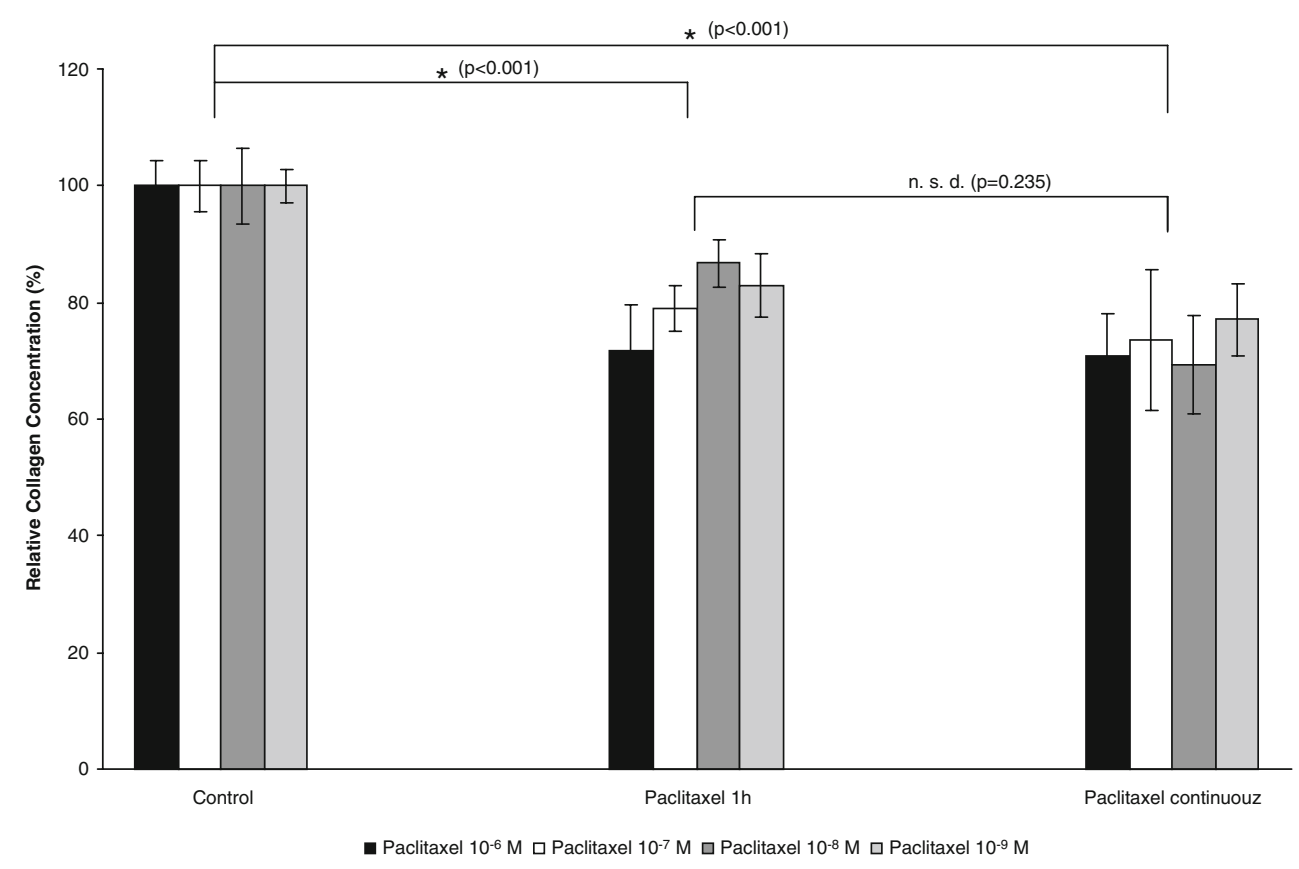

$10^{-8} \mathrm{~mol} / 1$ and $10^{-9} \mathrm{~mol} / 1$ respectively. Continuous exposure to paclitaxel led to apoptosis rates of $23.7 \pm 7.2 \%$, $17.3 \pm 7.9 \%, 9.9 \pm 3.0 \%$, and $2.4 \pm 1.0 \%$ for $10^{-6} \mathrm{~mol} / 1$, $10^{-7} \mathrm{~mol} / \mathrm{l}, 10^{-8} \mathrm{~mol} / 1$ and $10^{-9} \mathrm{~mol} / \mathrm{l}$. (Fig. 7a,b). The rate of necrotic cells remained very low and relatively stable

1 hour Exposure


$\neg$ Control $\rightarrow$ Paclitaxel $10^{-6} \mathrm{M} \rightarrow$ Paclitaxel $10^{-7} \mathrm{M} \leadsto$ - Paclitaxel $10^{-8} \mathrm{M} \rightarrow$ Paclitaxel $10^{-9} \mathrm{M}$

Fig. 7 Rates of apoptosis $(\mathbf{a}, \mathbf{b})$ and necrosis $(\mathbf{c}, \mathbf{d})$ after brief $(\mathbf{a}, \mathbf{c})$ or extended $(\mathbf{b}, \mathbf{d})$ exposure to paclitaxel at 1, 4 and 7 days after treatment over the entire observation period. It was highest in the samples continuously exposed to higher concentration of paclitaxel (Fig. 7c,d). Because of large variability between individual cell lines, and because only three of the seven cell lines were used for this assay, the apparent differences

between the treatment concentrations did not reach global statistical significance.

\section{Discussion}

Scarring of the Tenon's capsule and to a lesser extent of the scleral flap present the most prominent challenge to filtering glaucoma surgery. While the use of mitomycin C has greatly improved the success rate of this type of intervention, the associated failure rate of up to $45 \%$ at 5 years postoperatively remains high $[21,22]$. Repeated adjunctive injections of 5-FU as well as secondary procedures (e.g. needlings) are quite common, but yield only limited success. In addition, the most commonly used anti-proliferative substances have shown detrimental effects and complications such as choroidal detachment, hypotony, bleb leakage or blebitis, as well as cell loss of the corneal epithelium and endothelium, often leading to further, potentially permanent impairment of vision $[23,24]$. This may be a direct result of applying relatively high (and potentially toxic) doses of these substances for a very brief time. A potentially less toxic alternative could be the extended exposure of the filtering bleb to much lower doses of anti-fibrotic drugs.

Glaucoma drainage devices pose the unique opportunity of introducing a slow-release mechanism for low concentrations of anti-proliferative substances directly to the site of scar formation in filtering surgery. In animal models, several successful attempts have been made to improve the outcome of conventional filtering surgery by inserting drugeluting devices into the filtering bleb. Hydrogels as well as bio-degradable polymers have been used to incorporate a range of anti-proliferative substances in these animal studies [25-28].

In our study we investigated the effects of paclitaxel, a substance already used in drug-eluting coronary stents, on primary cultures of human Tenon's fibroblasts. Our results show that both short- and long-term exposure to low doses of paclitaxel inhibit growth and migration of the cells in a dose-dependent fashion. There were marked differences between the two exposure times, however. While the fibroblasts tolerated concentrations of paclitaxel as high as $10^{-7} \mathrm{~mol} / 1$ for 1 hour (cell proliferation was completely abolished at this concentration, see Fig. 1), the long-term exposure of the cells to even the low concentration of $10^{-9} \mathrm{~mol} / \mathrm{l}$ led to a significant decrease in cell count. Thus, a brief exposure of the scleral flap and conjunctiva to the compound during glaucoma surgery-similar to that of MMC - may be a suitable procedure for the application of higher concentrations of paclitaxel. On the other hand, concentrations even lower than the ones tested in our study may be sufficient to suppress scar formation by an extended release mechanism. As shown in animal studies, the longterm exposure to paclitaxel can be effective in preventing bleb scarring after filtering surgery $[25,26]$. More recently, Koz et al. showed that the slow elution of paclitaxel from hydrogels in rabbit eyes performed equally as well as MMC administered in the traditional fashion with respect to inflammatory response and fibrosis [27]. In a similar approach, Polak et al. showed that slow release of other anti-proliferative substances such as the anti-metabolites 5-fluorouracil (5-FU) and 5-chlorouracil (5-CU) from polymers implanted after filtering surgery has beneficial effects on long-term bleb development and intraocular pressure [28].

The effect of paclitaxel on HTF cell migration in our study was far less pronounced. Even though the effects were statistically significant already at low concentrations and brief exposure, only the long-term administration of the drug led to a biologically relevant decrease in cell migration (see Figs. 3 and 4). A study performed on rabbit Tenon's fibroblasts yielded similar results: in this investigation, the relatively high concentration of $10^{-6} \mathrm{~mol} / \mathrm{l}$ of paclitaxel was necessary to significantly inhibit TF cell migration [29].

Our investigation also showed a decrease in collagen release into the culture medium following the administration of paclitaxel. However, there was no correlation between the measured collagen concentration and the applied dose or exposure time in our study. One possible explanation could be that there may be no direct effect of paclitaxel on collagen synthesis. Human Tenon's fibroblasts are known to release TGF-beta 130$]$, a growth factor that stimulates collagen synthesis in these cells [31-33]. Paclitaxel has been shown to interfere with TGF-beta signaling [16, 17]. In our study, paclitaxel may have abolished the autocrine effects of TGF-beta ${ }_{1}$ released by the Tenon's fibroblasts themselves at all applied concentrations, thus reducing collagen production to a constitutive level. However, this remains speculative and further investigation is needed.

Since higher concentrations of paclitaxel led to changes in morphology of the cells (Fig. 5d), the question was raised whether cytotoxic effects may have been responsible for the lower cell count and decreased migratory activity observed. By assessing the rate of both apoptosis and necrosis, we were able to determine that paclitaxel does indeed lead to cell death in a dose-dependent fashion. However, the number of necrotic cells (as an indicator for direct toxicity) was relatively low in all samples, with the highest observed rate at $6.5 \%$ of the cells on day 4 of the samples continuously treated with $10^{-6} \mathrm{~mol} / 1$ of paclitaxel. By comparison, rates of necrosis as high as $9.4 \%$ have been reported for MMC after 5-minute exposure at a clinically used concentration [19]. 
Apoptosis appears to play a more prominent role, and is much more likely to have influenced the final number of cells in our experimental setting (Fig. 7). The apoptosis rate at the highest concentration in our study was lower than that of MMC as reported by Crowston et al., who saw 32\% apoptosis already at 48 hours [34], thus indicating that induction of apoptosis may also play a prominent role in the inhibition of bleb failure through use of MMC. In general, side-effects of paclitaxel should be similar in nature to those seen in MMC, as both compounds arrest the cell cycle. While paclitaxel interferes with the mitotic spindle, MMC's effects may be broader, because it intercalates in DNA and thereby probably does not only interfere with DNA replication but also with transcription and protein synthesis.

Interestingly, in our study the rate of apoptosis was very similar between brief and long-term exposure, which contrasts the observed differences in the growth rates between the applied concentrations. Thus, while cell death certainly influenced our growth and migration assays, it cannot fully explain the differences between the exposure times. Inhibition of proliferation by cell cycle arrest through stabilization of microtubules may be independent of-or start at lower concentrations than-induction of apoptosis.

The concentrations used in our study were lower than the systemic concentrations reached in oncological patients undergoing chemotherapy. A typical dose for ovarian cancer is $175 \mathrm{mg}$ per $\mathrm{m}^{2}$ of body surface [35]. This corresponds to approximately $5 \times 10^{-6} \mathrm{~mol} / 1$ in the extracellular fluid. The total dose of paclitaxel in coronary stents does not usually exceed $3 \mu \mathrm{g}$ per $\mathrm{mm}^{2}$ of contact area, and should not cause any systemic effects even if released instantaneously. Similarly, a coated GDD would not be very likely to cause systemic side-effects. Stability of paclitaxel in aqueous solutions is of some concern, as the compound is most stable at acidic $\mathrm{pH}$, and hydrolyses at neutral $\mathrm{pH}$ [36]. This is overcome in coronary stents by embedding the compound into biodegradable polymer coatings that control the release of the substance and thereby its exposure to the aqueous environment [37].

In conclusion, our study represents the first in vitro investigation of the effects of paclitaxel on primary cultures of human Tenon's fibroblasts. Our results indicate that paclitaxel may be an interesting candidate drug for the prevention of bleb scarring after filtering glaucoma surgery. Both short- and long-term exposure of human Tenon's fibroblasts to the compound resulted in a dose-dependent inhibition of proliferation and migration of the cells, with cytotoxic effects comparable to those of MMC. A biphasic release of paclitaxel from a glaucoma drainage device or a biodegradable spacer with a short initial peak, followed by a continuous elution of very low concentrations, may be an interesting mechanism for this substance. While MMC is firmly established in ophthalmology, paclitaxel may be advantageous in terms of development of a suitable coating for a drug-releasing device, due to years of experience with coated coronary stents. For this purpose, however, further investigations are needed to determine the compound's effects on the expression and release of collagen and other extracellular matrix components.

Acknowledgements This study was in part funded by the BiomaTiCS (Biomaterials, Tissues and Cells in Surgery) research group of the University of Mainz.

Open Access This article is distributed under the terms of the Creative Commons Attribution Noncommercial License which permits any noncommercial use, distribution, and reproduction in any medium, provided the original author(s) and source are credited.

\section{References}

1. Kim HY, Egbert PR, Singh K (2008) Long-term comparison of primary trabeculectomy with 5 -fluorouracil versus mitomycin $\mathrm{C}$ in West Africa. J Glaucoma 17:578-583

2. Reibaldi A, Uva MG, Longo A (2008) Nine-year follow-up of trabeculectomy with or without low-dosage mitomycin-c in primary open-angle glaucoma. Br J Ophthalmol 92:1666-1670

3. Casson R, Rahman R, Salmon JF (2001) Long term results and complications of trabeculectomy augmented with low dose mitomycin $\mathrm{C}$ in patients at risk for filtration failure. $\mathrm{Br} \mathrm{J}$ Ophthalmol 85:686-688

4. Picht G, Welge-Luessen U, Grehn F, Lutjen-Drecoll E (2001) Transforming growth factor beta 2 levels in the aqueous humor in different types of glaucoma and the relation to filtering bleb development. Graefes Arch Clin Exp Ophthalmol 239:199-207

5. Jampel HD, Roche N, Stark WJ, Roberts AB (1990) Transforming growth factor-beta in human aqueous humor. Curr Eye Res 9:963-969

6. Meyer-Ter-Vehn T, Grehn F, Schlunck G (2008) Localization of TGF-beta type II receptor and ED-A fibronectin in normal conjunctiva and failed filtering blebs. Mol Vis 14:136-141

7. Ayyala RS, Harman LE, Michelini-Norris B, Ondrovic LE, Haller E, Margo CE, Stevens SX (1999) Comparison of different biomaterials for glaucoma drainage devices. Arch Ophthalmol 117:233-236

8. Ayyala RS, Michelini-Norris B, Flores A, Haller E, Margo CE (2000) Comparison of different biomaterials for glaucoma drainage devices: part 2. Arch Ophthalmol 118:1081-1084

9. Kadri OA, Wilcox MJ (2001) Surface tension controls capsule thickness and collagen orientation in glaucoma shunt devices. Biomed Sci Instrum 37:257-262

10. Watson JC, Kadri OA, Wilcox MJ (2005) Effects of mitomycin C on glaucoma filtration capsules. Biomed Sci Instrum 41:394-399

11. Kurnaz E, Kubaloglu A, Yilmaz Y, Koytak A, Ozerturk Y (2005) The effect of adjunctive Mitomycin $\mathrm{C}$ in Ahmed glaucoma valve implantation. Eur J Ophthalmol 15:27-31

12. Cantor L, Burgoyne J, Sanders S, Bhavnani V, Hoop J, Brizendine E (1998) The effect of mitomycin C on Molteno implant surgery: a 1-year randomized, masked, prospective study. J Glaucoma $7: 240-246$

13. Costa VP, Azuara-Blanco A, Netland PA, Lesk MR, Arcieri ES (2004) Efficacy and safety of adjunctive mitomycin C during Ahmed Glaucoma Valve implantation: a prospective randomized clinical trial. Ophthalmology 111:1071-1076

14. Minckler DS, Vedula SS, Li TJ, Mathew MC, Ayyala RS, Francis BA (2006) Aqueous shunts for glaucoma. Cochrane Database Syst Rev (Online): CD004918 
15. Crown J, O'Leary M (2000) The taxanes: an update. Lancet 355:1176-1178, doi:S0140-6736(00)02074-2 [pii] 10.1016/S01406736(00)02074-2

16. Choi HS, Savard CE, Choi JW, Kuver R, Lee SP (2007) Paclitaxel interrupts TGF-betal signaling between gallbladder epithelial cells and myofibroblasts. J Surg Res 141:183-191, doi:S00224804(06)01183-8 [pii] 10.1016/j.jss.2006.12.558

17. Liu X, Zhu S, Wang T, Hummers L, Wigley FM, GoldschmidtClermont PJ, Dong C (2005) Paclitaxel modulates TGFbeta signaling in scleroderma skin grafts in immunodeficient mice. PLoS Medicine 2:e354, doi:05-PLME-RA-0231R2 [pii] 10.1371/ journal.pmed.0020354

18. Eisenberg MJ, Konnyu KJ (2006) Review of randomized clinical trials of drug-eluting stents for the prevention of in-stent restenosis. Am J Cardiol 98:375-382, doi:S0002-9149(06) 00725-9 [pii] 10.1016/j.amjcard.2006.02.042

19. Crowston JG, Wang XY, Khaw PT, Zoellner H, Healey PR (2006) Human serum reduces mitomycin-C cytotoxicity in human tenon's fibroblasts. Invest Ophthalmol Vis Sci 47:946-952, doi:47/3/946 [pii] 10.1167/iovs.05-1048

20. Ludbrook J (1994) Repeated measurements and multiple comparisons in cardiovascular research. Cardiovasc Res 28:303-311, doi:0008-6363(94)90127-9 [pii]

21. Giampani J Jr, Borges-Giampani AS, Carani JC, Oltrogge EW, Susanna R Jr (2008) Efficacy and safety of trabeculectomy with mitomycin C for childhood glaucoma: a study of results with long-term follow-up. Clinics (Sao Paulo) 63:421-426

22. Fontana H, Nouri-Mahdavi K, Lumba J, Ralli M, Caprioli J (2006) Trabeculectomy with mitomycin C: outcomes and risk factors for failure in phakic open-angle glaucoma. Ophthalmology 113:930-936

23. Hau S, Barton K (2009) Corneal complications of glaucoma surgery. Curr Opin Ophthalmol 20:131-136, doi:10.1097/ICU. 0b013e328325a54b 00055735-200903000-00013 [pii]

24. Mearza AA, Aslanides IM (2007) Uses and complications of mitomycin C in ophthalmology. Expert Opin Drug Saf 6:27-32

25. Jampel HD, Thibault D, Leong KW, Uppal P, Quigley HA (1993) Glaucoma filtration surgery in nonhuman primates using taxol and etoposide in polyanhydride carriers. Invest Ophthalmol Vis Sci 34:3076-3083

26. Jampel HD, Moon JI (1998) The effect of paclitaxel powder on glaucoma filtration surgery in rabbits. J Glaucoma 7:170-177

27. Koz OG, Ozhuy S, Tezel GG, Karaman N, Unlu N, Yarangumeli A, Kural G (2007) The effect of paclitaxel on conjunctival wound healing: a pilot study. J Glaucoma 16:610-615

28. Polak MB, Valamanesh F, Felt O, Torriglia A, Jeanny JC, Bourges JL, Rat P, Thomas-Doyle A, BenEzra D, Gurny R, Behar-Cohen F (2008) Controlled delivery of 5-chlorouracil using poly(ortho esters) in filtering surgery for glaucoma. Invest Ophthalmol Vis Sci 49:2993-3003
29. Joseph JP, Grierson I, Hitchings RA (1989) Taxol, cytochalasin $\mathrm{B}$ and colchicine effects on fibroblast migration and contraction: a role in glaucoma filtration surgery? Curr Eye Res 8:203215

30. Tripathi RC, Li J, Chalam KV, Tripathi BJ (1996) Expression of growth factor mRNAs by human Tenon's capsule fibroblasts. Exp Eye Res 63:339-346

31. Saika S, Yamanaka O, Kawashima Y, Ohkawa K, Ohnishi Y, Ooshima A, Kimura M, Nakano Y, Kao WW (1998) OPC-15161 suppresses the proliferation of Tenon's capsule fibroblasts and the production of type I collagen and fibronectin stimulated by TGFbetal in vitro. Curr Eye Res 17:933-940

32. Cordeiro MF, Bhattacharya SS, Schultz GS, Khaw PT (2000) TGF-beta1, -beta2, and -beta3 in vitro: biphasic effects on Tenon's fibroblast contraction, proliferation, and migration. Invest Ophthalmol Vis Sci 41:756-763

33. Kottler UB, Junemann AG, Aigner T, Zenkel M, Rummelt C, Schlotzer-Schrehardt U (2005) Comparative effects of TGF-beta 1 and TGF-beta 2 on extracellular matrix production, proliferation, migration, and collagen contraction of human Tenon's capsule fibroblasts in pseudoexfoliation and primary open-angle glaucoma. Exp Eye Res 80:121-134

34. Crowston JG, Chang LH, Constable PH, Daniels JT, Akbar AN, Khaw PT (2002) Apoptosis gene expression and death receptor signaling in mitomycin-C-treated human tenon capsule fibroblasts. Invest Ophthalmol Vis Sci 43:692-699

35. du Bois AQM, Thigpen T, Vermorken J, Avall-Lundqvist E, Bookman M, Bowtell D, Brady M, Casado A, Cervantes A, Eisenhauer E, Friedlaender M, Fujiwara K, Grenman S, Guastalla JP, Harper P, Hogberg T, Kaye S, Kitchener H, Kristensen G, Mannel R, Meier W, Miller B, Neijt JP, Oza A, Ozols R, Parmar M, Pecorelli S, Pfisterer J, Poveda A, Provencher D, PujadeLauraine E, Randall M, Rochon J, Rustin G, Sagae S, Stehman F, Stuart G, Trimble E, Vasey P, Vergote I, Verheijen R, Wagner U, Gynecologic Cancer Intergroup, AGO-OVAR, ANZGOG, EORTC, GEICO, GINECO, GOG, JGOG, MRC/NCRI, NCICCTG, NCI-US, NSGO, RTOG, SGCTG, IGCS, Organizational team of the two prior International OCCC (2005) 2004 consensus statements on the management of ovarian cancer: final document of the 3rd International Gynecologic Cancer Intergroup Ovarian Cancer Consensus Conference (GCIG OCCC 2004). Ann Oncol 16:viii7-viii12

36. Tian J, Stella VJ (2009) Degradation of paclitaxel and related compounds in aqueous solutions III: Degradation under acidic $\mathrm{pH}$ conditions and overall kinetics. J Pharm Sci, Sep 9 [Epub ahead of print], doi:10.1002/jps.21910

37. Halkin A, Stone GW (2004) Polymer-based paclitaxel-eluting stents in percutaneous coronary intervention: a review of the TAXUS trials. J Interv Cardiol 17:271-282, doi:JOIC4040 [pii] 10.1111/j.1540-8183.2004.04040.x 